\title{
EMMISION OF POLLUTANTS ORIGINATING FROM MOBILE SOURCES: THE EXAMPLE OF THE CITY OF KRAGUJEVAC
}

UDC 621.43.068:504.054(497.11Kragujevac)

\section{Zoran Marjanović, Miomir Raos, Milena Mančić, Jovana Randjelović}

University of Niš, Faculty of Occupational Safety, Niš, Serbia

\begin{abstract}
Traffic jam makes cities less pleasant for living and it also decreases traffic efficiency, whereas travel time, fuel consumption and drivers' level of stress are increased. A special problem is the influence of exhaust gas emissions on human health. The emission of pollutants originating from mobile sources is primarily conditioned by a level of technologies applied to the vehicle, vehicle technical condition, traffic intensity, traffic density, local climate conditions, etc. Air pollution from motor vehicles is becoming one of the major problems in urban areas across the world. With the increase in the number of motor vehicles and traffic intensification, the influence of exhaust gases on human environment has also increased. Considering the average age of the vehicles participating in traffic in the city of Kragujevac and the traffic capacity of traffic arteries, which are frequently not designed for large number of vehicles in the urban core, the air pollution from mobile sources is expected to become a problem that requires a thorough investigation. For that purpose, a detailed statistical analysis of the vehicle fleet of the city of Kragujevac is conducted. An estimation of the impact of the vehicles on air pollution in the city of Kragujevac has been given in the paper.
\end{abstract}

Key words: emission, exhaust gases, air quality

\section{INTRODUCTION}

In the middle of the twentieth century, with the increase in the number of cars, 2.6 billion people lived on the Earth and they owned around 50 million cars. In the new millennium, 5.7 billion people have over 500 million cars (with trucks and motorcycles around 800 million). In this period the population has doubled, while the number of cars has increased 10 times. Taking into account that around 50 million vehicles are produced annually in the world, it is expected that there will be around two billion passenger cars in the world in the next two decades [1].

Received October 12, 2018 / Accepted November 9, 2018

Corresponding author: Milena Mančić

University of Niš, Faculty of Occupational Safety in Niš, Čarnojevića 10a, 18000 Niš, Serbia

E-mail: milena.jovanovic@ znrfak.ni.ac.rs 
The degree of motorization is an indicator of the number of passenger vehicles (PV) per 1,000 inhabitants or the number of inhabitants per passenger vehicle. The developed world shows the tendency of expansionary growth to an approximate ratio of 350-400 PV/1,000 inhabitants or 2.8-2.5 inhabitants/PV. Such a degree of motorization roughly corresponds to a national income of about US \$ 7,500 per inhabitant [2].

In the complex city structure, traffic appears in three forms: through the street network, the number of motor vehicles, and the movement of vehicles through the urban environment. Road and street network through functional and physical classification, based on modern urban-traffic settings and planning-design requirements, is divided into a primary-road network (highways, roads, collecting streets) and secondary-road network (access roads, parking lots, sidewalks, pedestrian crossings). The primary network is designed for flowing traffic, and secondary provides access to certain goals [3].

The Kragujevac city area is connected with the rest of the road network of the Republic Serbia by the state roads of the first and the second class, while the rural settlements are mostly connected with local roads. In the territory of the city of Kragujevac there is the following road network categorization: $1^{\text {st }}$ class roads state roads first order - No. 1.11 (Kragujevac-Batocina) and No. 23 (Belgrade-Topola-Kragujevac-Ravni Gaj), $2^{\text {nd }}$ class roads No. 102 (Kragujevac - Kruševac) and No. 212 (Kragujevac - Gornji Milanovac) and municipal roads - 36 roads. The total length of roads in the territory of the city of Kragujevac is $440 \mathrm{~km}$, of which $309 \mathrm{~km}$ or $70 \%$ are modern roadways. In the categorized road network of the city Kragujevac, the significant share of municipal roads $(74.2 \%)$ is noticeably high compared to the rest of the categorized network. Also, the carriageway with modern pavement traffic comprises $82.7 \%$ of the municipal road network, which is significantly above the national average. However, the quality of the carriageway, the elements of the route and the status of the traffic signalization are not at the proper level. The mentioned data on the condition of the categorized road network show that the $2^{\text {nd }}$ and the $3^{\text {rd }}$ class state roads are below the average of the Republic of Serbia, whereas the municipal roads development is above the republican Serbian average. Based on the presented, it can be concluded that the local road network takes one part of the traffic, which increases the emissions of pollutants from mobile sources in the city of Kragujevac.

\section{The Share Of Motor Vehicle EMissions In Total AtMospheric POLlution}

The greatest impact on total air pollution in urban areas is caused by high concentration of motor vehicles, Figure 1.

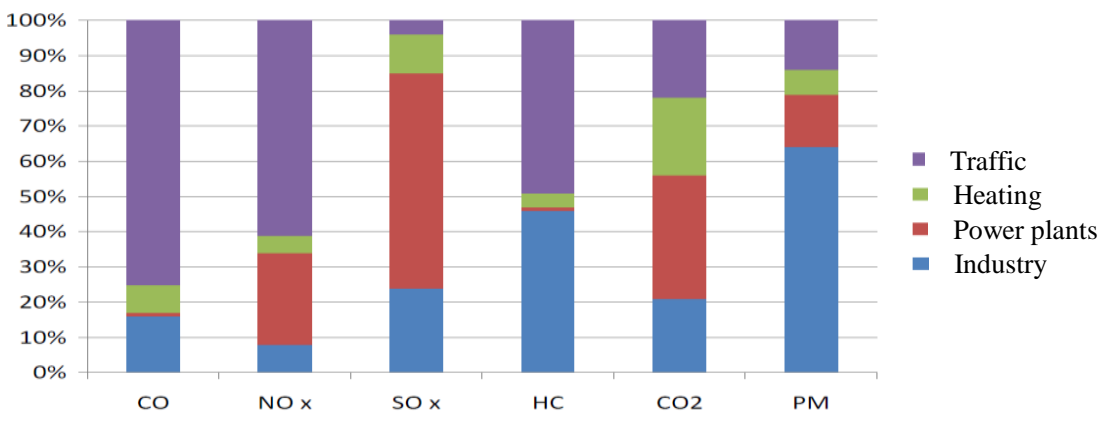

Fig. 1 Emission share from anthropogenic sources [4] 


\section{The CAR FleEt In the City Of KragujeVAC}

In the city of Kragujevac, the number of vehicles with catalytic converters and low emission of harmful substances is rather small due to economic situation of its inhabitants. The average age of the passenger vehicles on the streets of Kragujevac is 16 years old and 14 years old. They are in a relatively poor technical condition, and produce higher pollutant emissions than the modern ones. From the total car fleet in 2014, in Kragujevac, $30 \%$ of vehicles were older than 18 years, $90 \%$ were older than 5 years, and less than $1 \%$ were new vehicles. Table 1 shows the number of registered motor vehicles in the city of Kragujevac and in the Republic of Serbia, for the period from 2006 to 2014.

Table 1 Number of registered motor vehicles in the city of Kragujevac and in the Republic of Serbia [5]

\begin{tabular}{|c|c|c|c|c|c|}
\hline Vehicle type & $\begin{array}{c}\text { City of } \\
\text { Kragujevac } \\
\text { Serbia } \\
2006\end{array}$ & $\begin{array}{c}\text { City of } \\
\text { Kragujevac } \\
\text { Serbia } \\
2008\end{array}$ & $\begin{array}{c}\text { City of } \\
\text { Kragujevac } \\
\text { Serbia } \\
2010\end{array}$ & $\begin{array}{c}\text { City of } \\
\text { Kragujevac } \\
\text { Serbia } \\
2012\end{array}$ & $\begin{array}{c}\text { City of } \\
\text { Kragujevac } \\
\text { Serbia } \\
2014\end{array}$ \\
\hline \multirow[t]{2}{*}{ Motorcycles } & 169 & 1.965 & 2.873 & 2.337 & 2.582 \\
\hline & 18.627 & 33.753 & 38.229 & 34.362 & 38.100 \\
\hline \multirow{4}{*}{$\begin{array}{l}\text { Passenger } \\
\text { vehicles } \\
\text { Buses }\end{array}$} & 38.936 & 39.045 & 39.126 & 41.239 & 41.678 \\
\hline & 1.515 .824 & 1.537 .602 & 1.567 .192 & 1.726 .190 & 1.797 .252 \\
\hline & 192 & 184 & 178 & 183 & 186 \\
\hline & 9.160 & 8.874 & 8.034 & 8.834 & 9.043 \\
\hline \multirow[t]{2}{*}{ Trucks } & 2.590 & 3.544 & 3.485 & 2.973 & 3.675 \\
\hline & 122.188 & 182.690 & 162.799 & 144.075 & 190.908 \\
\hline \multirow{4}{*}{$\begin{array}{l}\text { Working } \\
\text { vehicles } \\
\text { Towing vehicles }\end{array}$} & 730 & 386 & 312 & 445 & 823 \\
\hline & 2.717 & 1.453 & 1.020 & 4.396 & 7.041 \\
\hline & 618 & 832 & 1.231 & 1.315 & 917 \\
\hline & 108.283 & 172.645 & 239.295 & 245.876 & 187.532 \\
\hline \multirow{2}{*}{$\begin{array}{l}\text { Connecting } \\
\text { vehicles }\end{array}$} & 1.267 & 978 & 1.393 & 667 & 2.124 \\
\hline & 93.375 & 55.766 & 99.025 & 33.389 & 144.559 \\
\hline \multirow[t]{2}{*}{ Total } & 44.502 & 46.934 & 48.598 & 49.159 & 51.985 \\
\hline & 1.870 .174 & 1.992 .783 & 2.115 .594 & 2.197 .122 & 2.374 .435 \\
\hline
\end{tabular}

The age structure of the vehicle also speaks of the unfavourable energy efficiency in transportation in the city of Kragujevac, which is conditioned by technological and constructive solutions which are old and outdated. Figure 2 shows the forecast of the renewal of the car fleet in the city of Kragujevac until 2022.

The economic situation in the city of Kragujevac is also reflected in the incomplete maintenance of the existing fleet, which contributes to the increase of emissions from mobile sources. Considering the poorly organized traffic in narrow streets that are often blocked by parked vehicles, the situation is even worse, since then vehicles are used in high-emission and fuel economy regimes. 


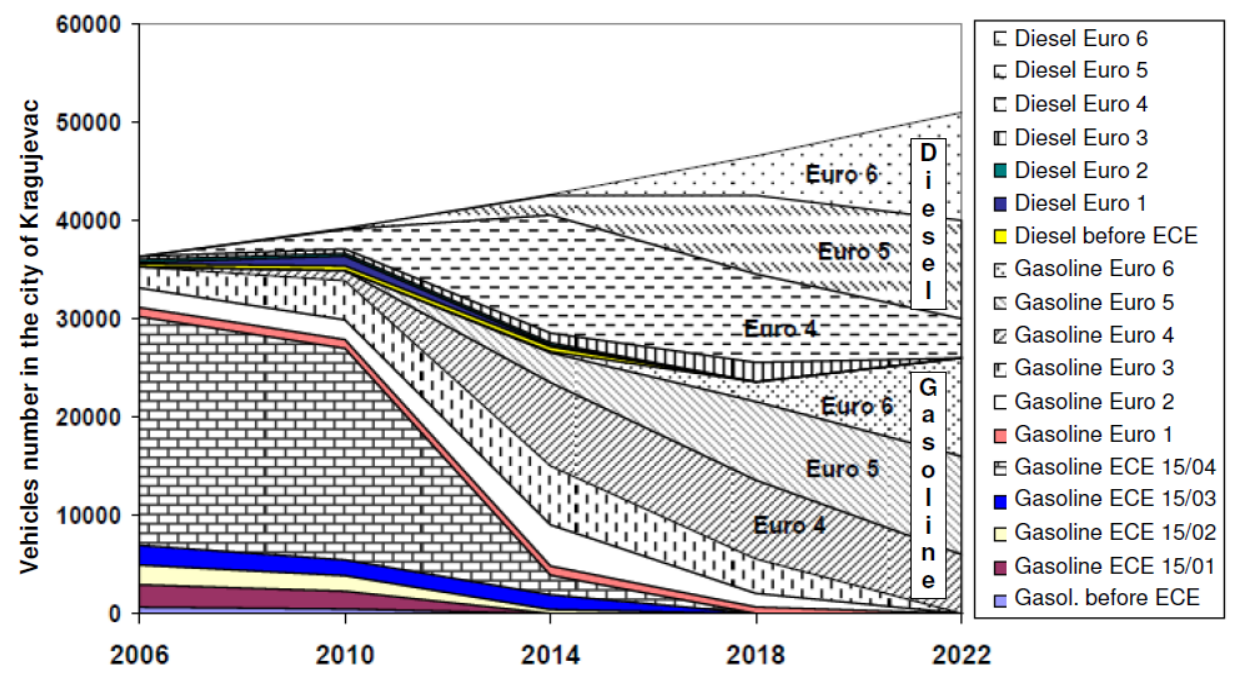

Fig. 2 Forecast of the renewal of the car fleet in the city of Kragujevac [6]

Combustion fuels in Serbian motor vehicles are below European standards because they have more polycyclic aromas than in developed countries, while diesel fuel has a lot of sulphur.

\section{EMISSIONS FROM MOBILE SOURCES}

Transport of passengers in the EU makes 75 to $90 \%$ of the total transport, transport of goods from 8 to $20 \%$, while transport by bus and motorbike makes only 1 to $2 \%$. About 400 million citizens of the European Union pass an estimated 2 billion kilometers annually, which means that every person per day, with their car, travels about $6 \mathrm{~km}$. It is obvious that motor vehicles participate in pollution to certain extent. Vehicle emissions are directly related to the model year and mileage (Table 2).

Table 2 Typical emission values and vehicle production years [3]

\begin{tabular}{lcccc}
\hline \multirow{2}{*}{ Production year } & \multicolumn{2}{c}{ The limit values } & \multicolumn{2}{c}{ Well-tuned engine } \\
\cline { 2 - 5 } & $\mathrm{CO}, \%$ & $\mathrm{HC}, \mathrm{ppm}$ & $\mathrm{CO}, \%$ & $\mathrm{HC}, \mathrm{ppm}$ \\
\hline before 1968 & $7,5-12,5$ & $750-2000$ & $2-3$ & $250-500$ \\
$1969-74$ & $7-11$ & $650-1250$ & $1,5-2,5$ & $200-300$ \\
$1975-80$ & $5-9$ & $425-1200$ & $1-1,5$ & $100-200$ \\
$1981-93$ & $3-6,5$ & $300-650$ & $0,5-1$ & $50-100$ \\
$1994-99$ & $1,5-3,5$ & $275-600$ & $0,3-1$ & $50-100$ \\
$2000-08$ & $1-2,5$ & $200-300$ & $0-0,5$ & $10-50$ \\
2009 and after & $1-1,5$ & $50-100$ & $0-0,2$ & $2-20$ \\
\hline
\end{tabular}

As it can be seen from the Table 2, vehicles that were designed and manufactured according to the 80's technologies have higher emissions than vehicles designed and manufactured in 1990 and more emissions than those designed and manufactured in 2000 
and 2010. The main reason is new and more efficient technologies for emission reduction in case of new vehicles. It is also noteworthy that vehicle emissions are rising with mileage.

Measurement of vehicle emissions in the city of Kragujevac was carried out by the Center for technical safety of vehicles of the Faculty of Mechanical Engineering in Kragujevac in 2011, in accordance with the EU Directive Council Directive 2003/27/EC. Figure 3 shows the results of measurements of passenger vehicle emissions of different ages and different manufacturers. The large percentage of Zastava's high-age vehicles in the city of Kragujevac speaks of the alarming state of the vehicle emissions in the city.
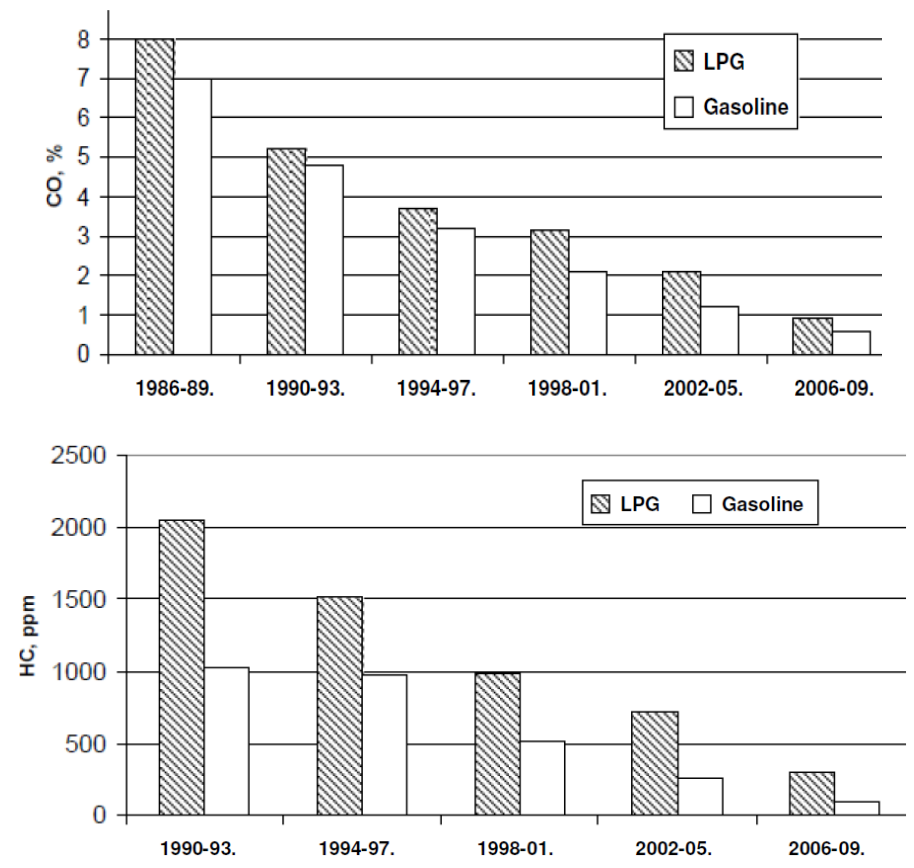

Fig. 3 Results of measurement of $\mathrm{CO}$ and $\mathrm{HC}$ passenger vehicle emissions in the city of Kragujevac (mean values)

Particular attention was paid to the emissions of vehicles with built-in equipment and equipment for LPG. More than $97 \%$ of the controlled vehicles had built-in simple devices, without any regulation of exhaust gases in the LPG drive. Only 3\% of LPG-powered vehicles had modern electronically controlled systems. The simplicity of the LPG powered vehicle and the lack of equipment and training of service technicians that install the equipment is the primary cause of significantly higher $\mathrm{CO}$ emissions and especially $\mathrm{HC}$ in vehicle handling with LPG. This is also supported by the fact that vehicles in the basic variant are designed and optimized to work with gasoline, and that any kind of remodeling, regardless of the fuel type, cannot reduce emissions without serious optimization. 


\section{MEASUREMENT OF AIR POLLUTANT EMISSIONS AT THE BUSIEST INTERSECTIONS IN THE CITY OF KRAGUJEVAC}

In the least 10 years, the calculation of the traffic load in the basic road network in Kragujevac pointed to the increased traffic load, which is especially in 2014 (according to the data from JP "Putevi Srbije"). For the local road network, there are no data on traffic load, and on the street network of the city of Kragujevac, segment-periodical traffic counts were carried out indicating an increase in the traffic load. The highest traffic density in the city of Kragujevac was registered at the Hala Jezero intersection, with 3,200 vehicles per peak hour (Table 3).

Table 3 Crossroads with peak flow in the city of Kragujevac

\begin{tabular}{lc}
\hline Crossroad per hour & Number of PV \\
\hline Hala Jezero & 3.200 \\
Medicinska skola & 2.400 \\
Mala vaga & 1.800 \\
\hline
\end{tabular}

In 2014, the concentrations of air pollutants (benzene, nitrogen dioxide and particles) were measured by the Institute of Public Health Kragujevac at the following intersections: at the crossroads Štafete, at Hale Jezero, at the Medicinska skola and at Mala vaga (Table 4).

Table 4 Emission of air pollutants originating from traffic at intersections in Kragujevac

\begin{tabular}{|c|c|c|c|c|c|c|}
\hline \multirow[b]{2}{*}{ Crossroad } & \multicolumn{2}{|c|}{ Benzen, $\mu \mathrm{g} / \mathrm{m}^{3}$} & \multicolumn{2}{|c|}{$\mathrm{NO}_{2}, \mu \mathrm{g} / \mathrm{m}^{3}$} & \multicolumn{2}{|c|}{$\mathrm{PM}, \mu \mathrm{g} / \mathrm{m}^{3}$} \\
\hline & $\begin{array}{l}\text { Maximum } \\
\text { concentration }\end{array}$ & $\begin{array}{l}\text { Number of } \\
\text { days above } \\
\text { ELV* }\end{array}$ & $\begin{array}{c}\text { Maximum } \\
\text { concentration }\end{array}$ & $\begin{array}{c}\text { Number of } \\
\text { days above } \\
\text { ELV* }\end{array}$ & $\begin{array}{c}\text { Maximum } \\
\text { concentration }\end{array}$ & $\begin{array}{c}\text { Number of } \\
\text { days above } \\
\text { ELV* }\end{array}$ \\
\hline Hala Jezero & - & - & 89 & 5 & 68 & 35 \\
\hline Medicinska škola & - & - & 86 & 4 & 56 & 22 \\
\hline Mala vaga & - & - & 88 & 2 & 52 & 18 \\
\hline Štafeta & 3,5 & 0 & 66 & 0 & 65 & 14 \\
\hline
\end{tabular}

From Table 4, we see that in 2014:

- The concentration of benzene measured in the city center (the crossroads Štafete) was not above the values allowed by law. The permissible emission limit value for benzene is $5\left[\mu \mathrm{g} / \mathrm{m}^{3}\right]$, the tolerance limit is $3\left[\mu \mathrm{g} / \mathrm{m}^{3}\right]$, and the maximum measured value was $3.5\left[\mu \mathrm{g} / \mathrm{m}^{3}\right]$ (date 15.01.2014). At other intersections, no benzene concentration measurement was performed.

- Concentrations of the $\mathrm{NO}_{2}$ at crossroads (measuring points), were within the values above ELV for an eleven-day period. The permitted emission limit value for $\mathrm{NO}_{2}$ is $85\left[\mu \mathrm{g} / \mathrm{m}^{3}\right]$, and the tolerance limit is $40\left[\mu \mathrm{g} / \mathrm{m}^{3}\right]$. At the crossroad Hala Jezero, the $\mathrm{NO}_{2}$ emission value was above the ELV for five days, and the highest measured value was $89\left[\mu \mathrm{g} / \mathrm{m}^{3}\right]$ (date 23.07.2014). At the crossroad Medicinska skola, the $\mathrm{NO}_{2}$ emission value was above the ELV for a four-day period, and the highest measured value was $86\left[\mu \mathrm{g} / \mathrm{m}^{3}\right]$ (date 01.11.2014). At the crossroad Mala vaga, the $\mathrm{NO}_{2}$ emission value was above the ELV for two days, and the highest measured value was 
$88\left[\mu \mathrm{g} / \mathrm{m}^{3}\right]$ (date 16.12.2014). Only the concentration of $\mathrm{NO}_{2}$ measured in the center of the city (the crossroads Stafeta) was not above the allowed limits, and the highest measured value was $66\left[\mu \mathrm{g} / \mathrm{m}^{3}\right]$ (date 10.01.2014).

- PM concentrations at crossroads were with values above the ELV for 89 days. The emission limit value for PM is $50\left[\mu \mathrm{g} / \mathrm{m}^{3}\right]$. At the crossroad Hala Jezero, the emission value for PM was above the ELV for 35 days, and the highest measured value was $68\left[\mu \mathrm{g} / \mathrm{m}^{3}\right]$ (date 26.12.2014). At the crossroad Medicinska škola, the emission value for PM was above the ELV for 4 days, and the highest measured value was $56\left[\mu \mathrm{g} / \mathrm{m}^{3}\right]$ (Date 08.07.201). At the crossroad Mala vaga, for 18 days, the emission value for PM was above the ELV, and the highest measured value was $52\left[\mu \mathrm{g} / \mathrm{m}^{3}\right], 29.12 .2014$. At the Štafeta, the emission value for the PM was above the ELV for 14 days, and the highest value was measured from $65\left[\mu \mathrm{g} / \mathrm{m}^{3}\right], 08.01 .2014$.

\section{CONCLUSION}

The problem of air pollution from motor vehicles will not be resolved substantially until the petrol used in the internal combustion engines is replaced by better-quality fuels with fewer emissions, or through the use of other sources of energy. The most developed countries have been encouraging the use of other, less harmful alternative drives.

In our country, the situation is even more unfavorable due to technically poorly maintained and almost exhausted vehicle fleet. The reality is even more confusing since it includes the data on almost 240,000 imported vehicles, which, regardless of their external preservation, are largely the automobile waste of Europe. The engines of such vehicles emit gases that are, in terms of quantity and composition of harmful components, outside of existing medical regulations and technical standards.

The Environmental Protection Agency in Serbia is in charge of monitoring the state of the environment and regular air quality measurements. The Environmental Protection Agency report for 2014 shows that the Serbian population is most exposed to pollution from particles and other powdery substances, which endanger human health and the ecosystems.

In Kragujevac, regular air control was conducted in 1975 by the Institute of Public Health Kragujevac. All measurements of exhaust gases at intersections in the city of Kragujevac confirm the devastating facts about air quality, especially when it comes to particle concentration. Based on the available and presented data on urban emission measurements, it can be said that traffic is the dominant source of air pollution throughout the year.

In order to reduce the emissions of particles from the bus in the city of Kragujevac, the company "Vulović transport" d.o.o. from Kragujevac in 2009, elaborated the study "Environmental and economic justification for the introduction of buses with natural gas drive" and submitted to the City Administration a project proposal entitled "Introduction of the natural gas buses into the city transport of Kragujevac". Unfortunately, this project remained in the experimental stage, (in which Vulović transport started using only two natural gas-powered buses), since it is necessary to build an adequate pumping infrastructure to increase the number of natural gas buses. 
In order to reduce emissions of pollutants from traffic in the city of Kragujevac, it is necessary:

- To stimulate the regular and proper maintenance of motor vehicles, and in that way significantly reduce their emissions and increase energy efficiency.

- To develop and adopt a traffic study of the city of Kragujevac, which should determine the guidelines for improving the traffic regime in the city.

- To develop, update and operationalize transport databases from the environmental aspect.

In the end, it should be emphasized that considering the economic conditions in the city of Kragujevac, in the near future, it is not realistic to expect a radical increase in the number of new modern vehicles. In such circumstances, the City environmental protection policy should strive to mitigate the consequences and systematize the latest world trends and development.

Acknowledgement: The paper is a part of the research done within the project III 43014.

\section{REFERENCES}

1. Cvetanović O.: Eksterni troškovi saobraćaja-ekološki aspekti razvoja saobraćaja i saobraćajne politike, Želnid, Beograd, 2007.

2. Biočanin R.: Zaštita i unapređenje životne sredine, knjiga, Učiteljski fakultet, Užice, 2009.

3. Gruden D.: Traffic and Environment, Springer-Verlag Berlin Heidelberg 2011, Nemačka, 2011.

4. Marjanović Z.: Istraživanje alternativnih pogona motornih vozila, doktorska disertacija, Fakultet zaštite na radu u Nišu, Niš, 2015 .

5. Republički zavod za statistiku Republike Srbije: Registrovana drumska i priključna vozila i saobraćajne nezgode na putevima 2004-2014., Beograd, 2015.

6. Trifunović S.: Studija o prošlim, sadašnjim i budućim ekološkim planovima na nivou Kragujevca i okoline, Eko centar, Kragujevac, 2013.

7. Gradska uprava za prostorno planiranje, izgradnju i zaštitu životne sredine grada Kragujevca: Ekološki bilten, broj $1 \div 12$, Kragujevac, 2014.

8. Institut za javno zdravlje Kragujevac: Godišnji rezultat kontrole kvaliteta vazduha za 2014. godinu, Kragujevac, 2015.

\section{EMISIJA ZAGAĐUJUĆIH MATERIJA POREKLOM IZMOBILNIH IZVORA NA PRIMERU GRADA KRAGUJEVCA2}

Povećani broj vozila u urbanim sredinama čini ih manje ugodnim za život, pri čemu smanjuje saobraćajnu efikasnost, povećava vreme putovanja, potrošnju goriva i stres učesnika u saobraćaju. Poseban problem predstavlja uticaj na zdravlje ljudi izazvane emisijom izduvnih gasova. Emisija zagađujucih materija poreklom iz mobilnih izvora uslovljena je pre svega nivoom primenjenih tehnologija na vozilu, njegovim tehničkim stanjem, intenzitetom saobraćaja, prohodnošću saobraćajnica, lokalnim meteorološkim uslovima itd. Pogoršanje kvaliteta vazduha usled korišćenja motornih vozila postaje jedan od najvećih problema urbanih sredina sirom sveta. Sa porastom broja motornih vozila $i$ intenziviranjem saobraćaja pojačao se i uticaj izduvnih gasova na životnu sredinu. Imajući u vidu prosečnu starost vozila prisutnih u saobraćaju u gradu Kragujevcu, propusnu moć saobraćajnica koje najčešće nisu projektovane za tako veliki broj vozila skoncentrisan u užem gradskom jezgru, realno je očekivati da je zagađivanje vazduha štetnim materijama iz mobilnih izvora ozbiljan problem koji zahteva detaljnu analizu. U tom cilju je izvršena detaljna statistička analiza voznog parka u gradu Kragujevcu $i$ data procena uticaja vozila na zagađenje vazduha.

Ključne reči: emisija, izduvni gasovi, kvalitet vazduha 